\title{
Report of first isolation of the zoonotic Arcobacter species from swine fecal samples in Ecuador
}

\author{
Rosa Janneth Simaluiza ${ }^{a}$, Jimmy Fernández ${ }^{a}$, Heriberto Fernández ${ }^{\text {b* }}$
}

\begin{abstract}
Arcobacter butzleri, A. cryaerophilus, A. skirrowii and A. thereius are recognised as emerging zoonotic agents, recovered from animals and human beings. The information available about Arcobacter species in Latin America is scarce. Among domestic animals, swine are considered important reservoir and source of contamination of different Arcobacter species. This communication reports the first simultaneous isolation of the four zoonotic Arcobacter species in Ecuador. Preliminary identification was done by phenotypic characteristics and definitive species identification was made by multiplex PCR method. Further investigation about the prevalence, distribution, ecology and interactions with human beings of these species is required.

Key words: Arcobacter, zoonotic species, reservoir, Ecuador.
\end{abstract}

\section{INTRODUCTION}

The genus Arcobacter, included into the family Campylobacteraceae, class Proteobacteria, subclass Gracillicutes, comprises aero-tolerant, curved or spiral rod shaped and polar flagellated bacteria, firstly described as Vibrio/Spirillum organisms and later as aero-tolerant Campylobacter-like organisms (Vandamme 2000, Fernández et al 1995, Collado and Figueras 2011).

Nowadays, genus Arcobacter comprises 27 validated species ${ }^{1}$ showing diverse habitats, being $A$. canalis the last described (Perez-Cataluña et al 2018). Some species live in association with a wide diversity of animals while others are found in environmental sources (Collado and Figueras 2011, Ferreira et al 2017). Only four of these species, A. butzleri, A. cryaerophilus, A. skirrowii and A. thereius are recognised as emerging zoonotic agents, being recovered from animals and human beings (Vandenberg et al 2004, Lehner et al 2005, Šilha et al 2015, van den Abeele et al 2015, Ferreira et al 2017).

It is important to highlight that among domestic animals, swine are considered important hosts, reservoir and source of contamination of different Arcobacter species (Ho et al 2006), and that in Latin America the information available about Arcobacter species is scarce. These bacteria have been isolated only in Chile (Fernández et al 1995), Argentina (Giacoboni et al 1997), Brazil (de Oliviera et al 1999), Mexico (Villarruel-López et al 2003), Peru (Zerpa et al 2015) and Costa Rica (Bogantes et al 2015). Thus, we conducted a pilot study in order to establish the

\footnotetext{
Accepted: 09.08.2018.

a Departamento de Ciencias de la Salud, sección de Genética Humana, Microbiología y Bioquímica Clínica, Universidad Técnica Particular de Loja, Loja, Ecuador.

${ }^{\text {b }}$ Facultad de Medicina, Instituto de Microbiología Clínica, Universidad Austral de Chile, Valdivia, Chile.

*Corresponding author: H Fernández; hfernand@uach.cl
}

$1 \quad$ http://www.bacterio.net/arcobacter.html presence of Arcobacter species in faecal samples obtained of healthy pigs at slaughterhouse.

\section{MATERIAL AND METHODS}

Twenty faecal samples were randomly taken by rectal swabs from healthy pigs, before the beginning of the slaughter at the slaughterhouse of Loja city, Southern Ecuador (359' Lat S; $79^{\circ} 12^{\prime}$ ' Long W).

To isolate Arcobacter sp., each sample was seeded into CAT (cefaperazone, amphotericin B and teicoplanin) enrichment broth and incubated at $30^{\circ} \mathrm{C}$ for $72 \mathrm{~h}$ under aerobic conditions (Collado et al 2013), followed by passive filtration through $0.45 \mu \mathrm{m}$ membrane filter placed on blood agar plates. After $30 \mathrm{~min}$ filtration, the filters were removed and the plates were incubated under the same conditions described above (Collado et al 2013, Fernández et al 2015). Preliminary identification of isolates was carried out by phenotypic characteristics [curved Gram negative rod, motility + , aerobic growth + , oxidase + and catalase + (Fernández et al 2015)]. Definitive species identification was done by the multiplex PCR (mPCR) method proposed by Douidah et al (2010) that characterizes the 5 most common Arcobacter species.

\section{RESULTS AND DISCUSSION}

Among the 20 faecal samples studied, three of them (15\%) were positive for Arcobacter sp. One yielded A. cryaerophilus, the second A. skirrowii and the third, A. butzleri and $A$. thereius simultaneously. These four species have been isolated from pigs in different parts of the world, including in some Latin American countries (Collado et al 2013, Fernández et al 2015, Barboza et al 2017, Ferreira et al 2017). However, so far as we know, in Latin America these four zoonotic have been reported simultaneously only in Costa Rica, especially in samples from poultry and food of animal origin (Barboza et al 2017).

The isolation rate $(15 \%)$ found in this pilot study falls within the ranges reported by De Smet et al (2011) 
in four Belgian pig farms where the isolation rates were $11.3,15.6,15.0$ and $50.0 \%$, and the isolated species were A. butzleri, A. cryaerophilus, A. skirrowii, A. thereius and A. trophiarum. However, it is higher than the $4 \%$ reported by Gobby et al (2018) in Brazil. The diversity of species found by these authors was restricted only to A. butzleri and A. cryaerophilus.

Arcobacter butzleri, A. cryaerophilus, A. skirrowii and A. thereius are currently recognised as emerging zoonotic agents isolated from different animals and human beings (Vandenberg et al 2004, Lehner et al 2005, Šilha et al 2015, van den Abeele et al 2015, Ferreira et al 2017). Since their main routes of transmission to humans are the consumption and handling of raw or undercooked foods of animal origin like meats, milk, seafood and water, they are also considered as potential foodborne pathogens (Vandenberg et al 2004, Lehner et al 2005, Collado et al 2013, Fernández et al 2015, Šilha et al 2015, van den Abeele et al 2015, Ferreira et al 2017). From these species, A. butzleri is the most frequently isolated from animal, environmental and human samples, followed by A. cryaerophilus, being both associated with abortion and enteritis in animals as well as with diarrhea and bacteremia in children and adults (Collado et al 2013, Šilha et al 2015, van den Abeele et al 2015, Ferreira et al 2017, Barboza et al 2017). Arcobacter skirrowii has been isolated from sheep and cattle with diarrhea, aborted pig foetus, and chronic and acute diarrhea in humans (Lehner et al 2005, Collado et al 2013, van den Abeele et al 2015, Ferreira et al 2017) whereas $A$. thereius has been isolated from pig's faecal samples, duck's cloacal samples and from livers and kidneys of pigs with spontaneous abortions. More recently, it was isolated from stool of hospitalised patients with diarrhoea (van den Abeele et al 2015, Ferreira et al 2017, Rovetto et al 2017).

In addition to these four zoonotic species of Arcobacter, other species of the genus have been isolated from pigs, such as A. thereius, A. throphiarum, A. suis and A. lanthieri (Whiteduck-Léveillée et al 2015). More recently Figueras et al (2017) established that $A$. thereius included a group strains (represented by strain LMG 24487) that clustered separately from the type strain (LMG 24486T) representing the new species Arcobacter porcinus. However, none of these species, except $A$. thereius, has been isolated from human beings until now. Bearing in mind that the zoonotic species of Arcobacter are considered as emerging species in human pathology, it is necessary to pay attention to the eventual presence of these other species in human clinical samples. Also, in the case of the isolation to $A$. thereius, it becomes necessary to differentiate it with $A$ porcinus. The PCR method used in this work (Douidah et al 2010) cannot differentiate $A$. porcinus from $A$. thereius, because it was developed before the proposal of Figueras et al (2017).

This communication reports the first simultaneous isolation of the four zoonotic Arcobacter species in
Ecuador allowing the identification of swine as one of their reservoir in this country.

Considering the zoonotic, emergent and foodborne character of these bacteria, we believe that it is important to establish their presence in other animal sources as well as in foods of animal origin, environmental waters and humans. This information will contribute to a better understanding of the epidemiology of these emerging foodborne enteropathogens as well as to evaluate the aplication of control actions from a food safety point of view.

\section{ACKNOWLEDGMENTS}

This work was financially supported by grant UTPL PROY_ CCSAL_1283.

\section{REFERENCES}

Barboza K, Cubillo Z, Castro E, Redondo-Solano M, Fernández-Jaramillo H, et al. 2017. First isolation report of Arcobacter cryaerophilus from a human diarrhea sample in Costa Rica. Rev Inst Med Trop 59, e72.

Bogantes EV, Fallas-Padilla KL, Rodríguez-Rodríguez CE, FernándezJaramillo H, Echandi ML. 2015. Zoonotic species of the genus Arcobacter in poultry from different regions of Costa Rica. J Food Prot 78, 808-811.

Collado L, Figueras M. 2011. Taxonomy, epidemiology, and clinical relevance of the genus Arcobacter. Clin Microbiol Rev 24, 174-192.

Collado L, Gutiérrez M, González M, Fernández H. 2013. Assessment of the prevalence and diversity of emergent campylobacteria in human stool samples using a combination of traditional and molecular methods. Diag Microbiol Infect Dis 75, 434-436.

De Oliveria SJ, Wesley IV, Baetz AL, Harmon KM, Kader IITA, et al. 1999. Arcobacter cryaerophilus and Arcobacter butzleri isolated from preputial fluid of boars and fattening pigs in Brazil. $J$ Vet Diagn Invest 11, 462-464.

De Smet S, De Zutter L, Debruyne L, Vangroenweghe F, Vandamme P, et al. 2011. Arcobacter population dynamics in pigs on farrow-to-finish farms. Appl Environ Microbiol 77, 1732-1738.

Douidah L, De Zutter L, Vandamme P, Houf K. 2010. Identification of five human and mammal associated Arcobacter species by novel multiplex-PCR assay. J Microbiol Methods 80, 281-286.

Fernandez H, Rojas X, Gajardo T. 1995. First isolation in Chile of Arcobacter cryaerophilus from a bovine abortion. Arch Med Vet 32, 111-114.

Fernandez H, Villanueva MP, Mansilla I, Gonzalez M, Latif F. 2015. Arcobacter butzleri and A. cryaerophilus in human, animals and food sources, in southern Chile. Braz. J Microbiol 46, 145-147.

Ferreira S, Oleastro M, Domingues F. 2017. Arcobacter spp. in food chain-from culture to omics. In: Singh OV (ed). Foodborne Pathogens and Antibiotic Resistance. Wiley-Blackwell, New Jersey, USA. Pp 73-118.

Figueras MJ, Pérez-Cataluña A, Salas-Massó N, Levican N. Collado L. 2017. 'Arcobacter porcinus' sp. nov., a novel Arcobacter species uncovered by Arcobacter thereius. New Microbe New Infect 15, 104-106.

Giacoboni G, Moredo F, Tobía M, Piazza D. 1997. Isolation of bacteria with biochemical characteristics of Arcobacter cryaerophilus in water of La Plata River, Argentina. Analecta Vet 17, 19-21.

Gobbi DDS, Spindola MG, Moreno LZ, Matajira CEC, Oliveira MGX, et al. 2018. Isolation and molecular characterization of Arcobacter butzleri and Arcobacter cryaerophilus from the pork production chain in Brazil. Pesq Vet Bras 38, 393-399.

Ho TKH, Lipman LJA, van der Graaf-van Bloois L, van Bergen M, Gaastra W. 2006. Potential routes of acquisition of Arcobacter species by piglets. Vet Microbiol 114, 123-133. 
Lehner A, Tasara T, Stephan R. 2005. Relevant aspects of Arcobacter spp. as potential foodborne pathogen. Int J Food Microbiol 102, 127-135.

Pérez-Cataluña A, Salas-Massó N, Figueras MJ. 2018. Arcobacter canalis sp. nov., isolated from a water canal contaminated with urban sewage. Int J Syst Evol Microbiol 68, 1258-1264.

Rovetto F, Carlier A, van den Abeele AM, Illeghems K, van Nieuwerburgh $\mathrm{F}$, et al. 2017. Characterization of the emerging zoonotic pathogen Arcobacter thereius by whole genome sequencing and comparative genomics. PLoS ONE 12, e0180493.

Šilha D, Šilhová HL, Vytřasová J. 2015. Modified isolation method of Arcobacter spp. from different environmental and food samples. Folia Microbiol 60, 515-521.

Van den Abeele AM, Vogelaerd D, Van Hende J, Hour K. 2015. Prevalence of Arcobacter species among humans, Belgium, 2008-2013. Emerg Infect Dis 20, 1731-1734.
Vandamme P. 2000. Taxonomy of the Family Campylobacteraceae. In: Nachamkin I, Blaser MJ (eds). Campylobacter. $2^{\text {nd }}$ ed. ASM Press, Washington, DC, USA, Pp 3-26.

Vandenberg O, Dediste A, Houf K, Ibekwem S, Souayah H, et al. 2004. Arcobacter species in humans. Emerg Infect Dis 10,1863-1867.

Villarruel-López A, Márquez-González M, Garay-Martínez LE, Zepeda H, Castillo A, et al. 2003. Isolation of Arcobacter spp. from retail meats and cytotoxic effects of isolates against Vero cells. J Food Prot 66, 1374-1378.

Whiteduck-Léveillée K, Whiteduck-Léveillée J, Cloutier M, Tambong JT, Xu R, et al. 2015. Arcobacter lanthieri sp. nov., isolated from pig and dairy cattle manure. Int J Syst Evolut Microbiol 65, 2709-2716,

Zerpa R, Alarcón J, Lezama P, Patiño L, Reyes A, et al. 2014. Identification of Arcobacter in children and adult feces with/without diarrhea, and in animal reservoirs. An Fac Med 75, 185-187. 
